\title{
Stemphylium Solani Stabilized the Physicochemical Characteristics of Host Plant Species During Stress
}

\author{
Ismail Ismail ${ }^{1}$, Muhammad Hamayun ${ }^{1 *}$, Anwar Hussain ${ }^{1}$, Amjad Iqbal', \\ Sumera Afzal Khan ${ }^{3}$, Ayaz Ahmad ${ }^{4}$, Sarah Gul, Ho-Youn Kim ${ }^{6}$, In-Jung Lee ${ }^{7 * *}$ \\ ${ }^{1}$ Department of Botany, Abdul Wali Khan University Mardan, Pakistan \\ ${ }^{2}$ Department of Food Science \& Technology, Abdul Wali Khan University Mardan, Pakistan \\ ${ }^{3}$ Centre of Biotechnology and Microbiology, University of Peshawar, Pakistan \\ ${ }^{4}$ Department of Biotechnology, Abdul Wali Khan University Mardan, Mardan, Pakistan \\ ${ }^{5}$ Department of Biological Sciences, FBAS, International Islamic University, Islamabad, Pakistan \\ ${ }^{6}$ Smart Farm Research Center, Korea Institute of Science and Technology (KIST), Gangwon, Korea \\ ${ }^{7}$ Department of Applied Biosciences, Kyungpook National University, Daegu 41566, Korea
}

Received: 21 April 2021

Accepted: 23 June 2021

\begin{abstract}
Most of the plant species are susceptible to various ecological constraints, including high temperature stress. Endophytic fungi can defend the host crops from the extreme effects of thermal stress. We isolated fungal endophytes from a wild plant species Sonchus asper L. to study its effect on the physicochemical characteristics of Helianthus annuus L. and Glycine max L. exposed to high temperature stress. Biochemical and physiological parameters, such as chlorophyll contents, total biomass and height of the Helianthus annuus and Glycine max were promoted, whereas the production of ROS (Reactive Oxygen Species) and lipid peroxidation were inhibited in the fungal inoculated plants. Furthermore, higher amounts of ROS-degrading antioxidants [CAT (catalase), SOD (superoxide dismutase), POD (peroxidase), GR (glutathione-reductase) and AAO (ascorbic acid oxidase)], sugars, proteins, lipids and phenolics were noted in host crops. Lower concentration of proline and ABA on the other hand was observed in plants inoculated with fungal strain and exposed to heat stress. The potent strain was found to be Stemphylium solani after amplification of the ITS region of $18 \mathrm{~S}$ rDNA. The results concluded that $S$. solani can be handy in mitigating heat stress in food crops.
\end{abstract}

Keywords: endophytic fungi, Stemphylium solani, Sonchus asper, heat stress, antioxidants

e-mail: ijlee@knu.ac.kr

**e-mail: hamayun@awkum.edu.pk 


\section{Introduction}

Thermal stress is considered an insistent abiotic stress responsible for massive damage to various food cultivated crops [1-4]. High temperature is responsible for enhanced vaporization from land surface not only harm the plants due to drought, but also cause soil salinity [5]. Static nature of plants, further expose plants to biotic and abiotic pressures, resulting in damages to chlorophylls, lipids and proteins through enhanced production of reactive oxygen species or ROS [6]. ROS species comprising $\mathrm{H}_{2} \mathrm{O}_{2}$ (Hydrogen Peroxide), $\mathrm{OH}$ (Hydroxyl Radical), $\mathrm{O}_{2}^{-1}$ (superoxide) and ${ }^{1} \mathrm{O}_{2}$ (Singlet Oxygen) can degrade proteins, lipids and chlorophyll [7-10].

In fact, plants consist of self-activated defense mechanisms (SADMs) that further comprised of antioxidant system responsible for plant defense against oxidative damages [11]. Plants have the ability to transport the harmful ions to the tissues that have low sensitivity to such ions [12]. Besides, plants have a strong enzymatic [AAO (Ascorbic acid oxidase), GR (Glutathione-reductase), CAT (Catalase), SOD (Superoxide dismutase) and POD (Peroxidase)] and non-enzymatic antioxidant system (tocopherol, poly phenols flavonoids, etc.) [13]. Phytohormones [jasmonic acid (JA), salicylic acid (SA) and abscisic acid (ABA)] are vital signaling compounds during diverse abiotic and biotic shocks [14-19]. ABA act as key hormone that respond to the drought and thermal stresses by controlling the opening and closing of stomata [20]. Moreover, ABA plays a vital part in the germination of seeds in vascular plants (Arabidopsis thaliana), their development and maturation, and senescence [21]. In higher plants, phenolics and proline are accrued in response to abiotic strains (salinity, drought, light intensity, ultra violet rays, low and high temperature). The plant phenolics and proline compounds function as ROS scavengers, proteins and membranes stabilizers, and have the ability to buffer cellular oxidation-reduction reactions $[7,8]$.

Endophytes (bacteria and/or fungi) have the ability to reside inside the living tissues of the majority of plants as endo-symbiotic allies eternally or temporarily without causing any damages to their host [6, 18, 22-25]. Fungal endophytes are considered to have a protective role in host plants against various ecological constrain. Endophytes can help with restoration of host plant growth by accelerating mineral absorption, decreasing disease harshness and improving biomass synthesis under stress [26, 27]. It is recognized that plants hosting fungal endophytes have extra resistance to various ecological pressures (low and high temperature, drought, salinity, light intensity and ultraviolet rays) as compared to the plants lacking in endophytes [7, 23, 24, 28]. Hence, the aim and objective of the present project were to explore the stress tolerating endophytic strains that can help the important crop species, such as Helianthus annuus and Glycine max to stand the thermal stress.

\section{Materials and Methods}

The seeds of H. annuus (ICI Hyson 33) and G. max (Swat 84) were grown in small plastic pots containing $100 \mathrm{~g}$ of autoclaved sand for two weeks in growth chambers set at $25^{\circ} \mathrm{C}$ and $40^{\circ} \mathrm{C}$. A light intensity of $472.5 \mu \mathrm{mol} \mathrm{m} \mathrm{m}^{-2} \mathrm{~s}^{-1}, 12 \mathrm{~h}$ of day/night cycle, $70 \%$ relative humidity $(\mathrm{RH})$ was maintained in growth chambers operated at $25^{\circ} \mathrm{C}$ or $40^{\circ} \mathrm{C}$. All the experiments were performed in triplicates.

\section{Isolation of Fungal Endophytes}

Sonchus asper L., collected from Noshera District, Khyber Pakhtunkhwa, Pakistan was used for the isolation of endophytes according to the standardized protocol of Benizri, et al. [29]. S. asper is a wild species and can be found in places that undergo hot summer. It is due to heat standing ability that we have selected $S$. asper to isolate endophytes for the amelioration of heat stress. Initially, S. asper plants were collected in plastic zip bags and brought to the laboratory. The plants were thoroughly washed with tap water to remove dirt. The dirt free plants were surface sterilized with $70 \%$ ethanol for 2 minutes and then 5\% sodium hypochlorite $(\mathrm{NaOCl})$ for 5 minutes. The pants were rinsed with distilled water to remove traces of ethanol and $\mathrm{NaOCl}$. The sterilized plants were cut into pieces $(1-2 \mathrm{~cm})$ and 5 pieces were placed in Petri Plates containing Hagem media. The plates were shifted to the incubator and incubated at $28^{\circ} \mathrm{C}$ till the appearance of fungal colonies. Individual colonies were obtained by repeated culturing on PDA plates.

\section{Preliminary Screening of Isolated Fungus on $O$. sativa Seedlings}

The potency of fungal strain was initially screened on rice seedlings at the two leaf stage. Fresh biomass of $S$. solani was added to a conical flask containing $50 \mathrm{~mL}$ of the Czapek broth. The flask was placed in a shaking-incubator set at $120 \mathrm{rpm}$ and $28^{\circ} \mathrm{C}$ for a week. After one week of incubation, the Czapek medium was filtered through Whatmann No.1 filter paper and the culture filtrate was collected for further use. Rice variety Fakhr-e-Malakand was taken and culture filtrate $(100 \mu \mathrm{L})$ was applied to the tip of rice seedlings grown in water-agar medium $(0.8 \%)$ in a growth-chamber under conditions as described earlier. After one week of incubation, root and shoot length, fresh and dry weight of root and shoot, and total chlorophyll contents of the treated rice seedlings were calculated. Rice seedlings from control treatments were treated with distilled water or Czapek broth [30]. 


\section{Molecular Identification of Fungal Isolate SonchL-27}

The method of Khan, et al. [31] with minor modification was adopted for the identification of AdR13 endophyte. The primers ITS1 (5'-TCC GTA GGT GAA CCT GCG G-3') and ITS4 (5'-TCC TCC GCT TAT TGA TAT GC-3') were utilised in the amplification of 18S rRNA. To find sequence homology approximation, the BLASTn1 program was used. The phylogenetic consensus tree was constructed through neighbor joining (NJ) method using MEGA 7 software.

The method of Khan, et al. [31] was adopted for the isolation of AdR13 DNA. Initially, microfuge was taken and transferred $500 \mu \mathrm{L}$ of $5 \%$ of sodium dodecyl sulfate in bead beating solution. The mycelium $(200 \mathrm{mg}$ ) of AdR13 was then added to the microfuge tube and the contents of the tube were mixed by using vortex. suspended in the microfuge tube containing $500 \mu \mathrm{L}$ of a bead beating solution and 5. After mixing the contents of the microfuge tube, it was transferred to the centrifuge, where it was centrifuged at $4{ }^{\circ} \mathrm{C}$ and $11,000 \mathrm{~g}$ for 10 minutes. The supernatant $(0.5 \mathrm{~mL})$ was collected with great care and transferred to a fresh tube. To the supernatent, added equal volumes of phenol: chloroform: isoamyl alcohol $(25: 24: 1)$ and the contents were mixed with the help of vortex. The vortexed sample was centrifuged again for 5 minutes at $10,000 \mathrm{~g}$. Isopropanol $(2.5 \mathrm{~mL})$ was then added to the collected supernatant and the tube was transferred to the refrigerator, where it was kept for an hour. After incubation in refrigerator the contents of the tube was centrifuged for 10 minutes at $14,000 \mathrm{~g}$. The DNA was precipitated in the form of pellete. Cold ethanol $(70 \%)$ was used to wash the pellet in order to wash out all the impurities. After air drying, $40 \mu \mathrm{L}$ of TE buffer was added to re-suspend the pellete and the DNA was quantified at $260 \mathrm{~nm}$ through Thermo Scientific Nano Drop spectrophotometer [32.]

\section{Inoculation of $S$. solani to $G$. $\max$ and $H$. annuus}

Fresh fungal biomass $(1 \mathrm{mg})$ was mixed with 100 $\mathrm{g}$ of autoclaved sand. After thorough mixing of fungal biomass with autoclaved sand, it was transferred to the pots. To each pot, 9 seeds of $H$. annuus or G. $\max$ were sown. The pots were moved to the growth chambers for 14-days. The temperature of the growth chambers was maintained at $25^{\circ} \mathrm{C}$ or $40^{\circ} \mathrm{C}$. Hoagland solution (10 mL; Half strength) was employed to the plants at two days interval till the end of the experiment. The growth attributes were finally measured after the termination of the experiment [33,34]. Lengths of plants were measured with a scale, whereas fresh weight of plants were measured with the help of an analytical balance. To measure the plant dry weight, the roots and shoot of the test species were initially dried in an oven operated at $105^{\circ} \mathrm{C} \pm 1$ for 12 hours. The dried weight was then measured using the analytical balance. Chlorophyll meter (Spad-502 plus, Japan) was used to compute the chlorophyll contents in the test crop species.

\section{Determination of Antioxidants}

The protocol of Luck [35] was adopted to estimate the activity of catalase in test crop species, i.e. $H$. annuus and G. max. Leaves of the test crop species $(2 \mathrm{~g})$ were crushed in a $10 \mathrm{~mL}$ of phosphate buffer. The resultant homogenate was collected and centrifuged for 5 minutes at $10,000 \mathrm{rpm}$. The supernatant $(40 \mu \mathrm{L})$ was carefully moved to a tube containing $\mathrm{H}_{2} \mathrm{O}_{2}$-phosphate buffer $(3 \mathrm{~mL})$ with the help of micropipette. After mixing the contents of the tube, absorbance $($ Abs. $=240 \mathrm{~nm})$ was measured with help of spectrophotometer. Estimation of the peroxidase activity (enzyme units/mg protein) was carried ou by the method of Kar and Mishra [36]. Approximately, 20X diluted enzyme extract $(1 \mathrm{~mL})$ was mixed with $4 \mathrm{~mL}$ of $50 \mu$ moles $\mathrm{H}_{2} \mathrm{O}_{2}+50 \mu$ moles pyrogallol $+125 \mu$ moles of phosphate buffer ( $\mathrm{pH}$ 6.8). Incubation of the mixture was done at $25^{\circ} \mathrm{C}$ for 5 minutes. $\mathrm{H}_{2} \mathrm{SO}_{4}$ $(5 \% \mathrm{v} / \mathrm{v})$ was then added to stop the reaction and the concentration of purpurogallin was estimated with the help of spectrophotometer (Abs. $=420 \mathrm{~nm}$ ). The activity of ascorbate oxidase was measured by a well established protocol [37]. Leaves of the test crop species $(0.1 \mathrm{~g})$ was crushed in $2 \mathrm{~mL}$ of phosphate buffer and the mixture was centrifuged at $3000 \mathrm{~g}$ for 5 minutes. The collected supernatnt $(100 \mu \mathrm{L})$ was mixed with a substrate solution $(3 \mathrm{~mL})$. The substrate solution was comprised of ascorbic acid (8.8. $\mathrm{mg}$ ) and phosphate buffer of $\mathrm{pH}$ $5.6(300 \mathrm{~mL})$. The absorbance $($ Abs. $=265 \mathrm{~nm})$ was observed for 5 minutes at intervals of 30 seconds with the help of spectrophotometer. The superoxide dismutase activity in the test crops was calculated by the procedure of Beyer Jr and Fridovich [38]. Fresh leaves $(0.5 \mathrm{~g})$ of the test crop species were taken in a morter and crushed with the help of pestle in a $1 \mathrm{~mL}$ of potassium phosphate $(50 \mathrm{mM})$ + EDTA $(1 \mathrm{mM} ; \mathrm{pH} 7.5)$. The resulted homogenate were transferred to centrifuge tubes for centrifugation. This step was done at $43000 \mathrm{~g}$ and $4^{\circ} \mathrm{C}$ for 15 minutes. The collected supernatant $(50 \mu \mathrm{L})$ was then consumed to estimate the activity of SOD by mixing it with a reaction mixture $[1 \mathrm{mM}$ EDTA, $13 \mathrm{mM}$ L-methionine, $75 \mu \mathrm{M}$ nitro blue tetrazolium (NBT) in $50 \mathrm{mM}$ potassium phosphate buffer ( $\mathrm{pH} 7.8)]$. A $2 \mu \mathrm{M}$ of riboflavin was then added to initiate the reaction. The SOD activity was measured as an increase in the optical density of nitroblue tetrazolium (NBT) after 1 minute of the reaction under standard conditions at $560 \mathrm{~nm}$. The amount of SOD was determined as enzyme units/mg protein. An enzyme unit is defined as the amount of protein consumed to cause $50 \%$ inhibition of NBT reduction. The method of Carlberg and Mannervik [39] was adopted to measure the activity of glutathione reductase. The GR activity was characterized by the reduction of 
glutathione (GSSG) by NADPH at an optical density of $340 \mathrm{~nm}$. Initially, a reaction mixture was made, which was composed of NADPH $(0.125 \mathrm{mmol} / \mathrm{L})$, GSSG $(1 \mathrm{mmol} / \mathrm{L})$, EDTA $(1 \mathrm{mmol} / \mathrm{L})$ in potassium phosphate buffer $(100 \mathrm{mmol} / \mathrm{L} ; \mathrm{pH}$ 7.0). Fresh leaves of the test crops were crushed in the morter with help of pistle in the presence of liquid nitrogen, EDTA $(1 \mathrm{mmol} / \mathrm{L})$, Triton X-100 $(0.1 \% \mathrm{v} / \mathrm{v})$, dithiothreitol $(2 \mathrm{mmol} / \mathrm{L})$ in $100 \mathrm{mmol} / \mathrm{L}$ Tris- $\mathrm{HCl}(\mathrm{pH})$. The homogenate was centrifuged 27,000 g to collect the supernatant. Added, $200 \mu \mathrm{L}$ of the sample supernatant to $0.8 \mathrm{~mL}$ of the reaction mixture and the optical density was observed with the help of spectrophotometer (Abs. $=340 \mathrm{~nm}$ ).

\section{Determination of ABA}

Estimation of ABA in $H$. annuus and $G$. $\max$ seedlings was done according to the method of Yoon, et al. [40]. Fresh leaves $(0.5 \mathrm{~g})$ of $H$. annuus and $G$. max were pulverized in liquid $\mathrm{N}_{2}$. The homogenate was then added to the $2 \mathrm{~mL}$ mixture, composed of isopropanol $(1.5 \mathrm{~mL})$ and glacial acetic acid $(28.5 \mathrm{~mL})$. The resultant mixture was concentrated in rotary evaporated and then filtered. Diazomethane was added to the mixture and was examined via GC MS SIM (6890N setup GC Scheme furnished with 5973 System Mass Selective Detector; Agilent Technologies, Palo Alto, CA, USA). The Lab Base, Thermo Quset, Manchester, UK, Data System Software (DSS) was used to monitor retorts to ions with $\mathrm{m} / \mathrm{z}$ standards of 190 and 162 for Me-ABA and 194 and 166 for Me-[2H6]-ABA. ABA ([2H6]-ABA) was applied as standard.

\section{Determination of Phenolics and Proline}

Estimation of total phenolics in test crop species were measured by the established protocol of Cai, et al. [41]. To the sample $(0.2 \mathrm{~mL}), 0.5 \mathrm{~N}$ of the FolinCiocalteu reagent was added and the mixture was kept for 4 minutes at $25^{\circ} \mathrm{C}$. Sodium carbonate $(75 \mathrm{~g} / \mathrm{L})$ was then added and the contents were heated for $1 \mathrm{~min}$ at $100^{\circ} \mathrm{C}$. The heated mixture was transfeered to the dark place and incubated for 2 hours. After 2 hours of incubation, the absorbance were measured at $650 \mathrm{~nm}$. Gallic acid (Sigma Aldrich) at different concentartions 100, 200, 300, 500, 600, 700, and $900 \mathrm{mg} / \mathrm{ml}$ ) was utilized to draw a standard curve. The concentration of proline in the test crops were estimated by an established method [42], but with minor modifications. Fresh leaves $(0.1 \mathrm{~g})$ of the test crops were pulverized in $3 \%$ of sulpho-salicylic acid $(4 \mathrm{~mL})$. The pulverized tissues in sulpho-salicylic acid was incubated for 24 hours at $5^{\circ} \mathrm{C}$. After incubation, the homogenate was centrifuged at $3000 \mathrm{rpm}$ for $5 \mathrm{~min}$. A supernatant $(2 \mathrm{~mL})$ was mixed with acid ninhydrin $(2 \mathrm{~mL})$ and heated at $100^{\circ} \mathrm{C}$ for 1 hour. Toluene $(4 \mathrm{~mL})$ was finally added to the mixture and the absorbance was checked with the help of spectrophotometer (Abs. $=520 \mathrm{~nm})$.
Pure proline (Sigma Aldrich) at various concentrations $(2,4,6,8$, and $10 \mu \mathrm{g} / \mathrm{ml})$ was used to construct a standard curve.

\section{Determination of Total Sugars, Lipids and Proteins}

Methodology of Lowry, et al. [43] was used for the estimation of proteins in $H$. annuus and $G$. max seedlings. Homogenate of filtered leaf sample $(0.1 \mathrm{~mL})$ was mixed with $0.1 \mathrm{~mL}$ of $\mathrm{NaOH}(2 \mathrm{M})$ and then hydrolyzed at $100^{\circ} \mathrm{C}$. The hydrolysate was allowed to cool and then mixed with $1 \mathrm{~mL}$ of complex-forming solution [complex-forming solution $=2 \%(\mathrm{w} / \mathrm{v}) \mathrm{Na}_{2} \mathrm{CO}_{3}$ in distilled $\mathrm{H}_{2} \mathrm{O}, 1 \%(\mathrm{w} / \mathrm{v}) \mathrm{CuSO} 4.5 \mathrm{H}_{2} \mathrm{O}$ in distilled $\mathrm{H}_{2} \mathrm{O}, 2 \%$ (w/v) sodium potassium tartrate in distilled $\mathrm{H}_{2} \mathrm{O}$ ]. The mixture was allowed to stand for 10 minutes at room temperature. Folin reagent $(1 \mathrm{~mL})$ was added to the mixture and the solution was vortexed. The vortexed sample was again allowed to stand for 30 minutes at room temperature. The absorbance was lastly measured at $650 \mathrm{~nm}$. Different concentrations of bovine serum albumin (BSA) (Sigma Aldrich; 20, 40, 60,80 , and $100 \mu \mathrm{g} / \mathrm{ml}$ ) was applied to draw a standard curve. The methodology of Van Handel [44] was adopted to estimate the total lipids in $H$. annuus and $G$. max seedlings. Leave of the $H$. annuus or $G$. max were crushed in $1 \mathrm{~mL}$ of $2 \%$ sodium sulfate. The homogenate was centrifuged at $11000 \mathrm{~g}$ for 5 minutes and about 1 $\mathrm{mL}$ of the supernatant was taken and transferred to the reaction tubes containing $1 \mathrm{~mL}$ chloroform/methanol $(1: 2 \mathrm{v} / \mathrm{v})$ solution. The mixture was heated on a water bath at $90^{\circ} \mathrm{C}$ until complete evaporation. Concentrated sulfuric acid $(2 \mathrm{ml})$ was added to dissolve the precipitate. The mixture was again heated on a water bath for 20 minutes at $90^{\circ} \mathrm{C}$. After cooling the mixture, added $5 \mathrm{~mL}$ of vanillin-phosphoric acid reagent and the mixture was allowed to stand for 30 minutes at room temperature for the development of colour. Finally, the tubes were mixed and the absorbance was recorded at $525 \mathrm{~nm}$. Various concentrations of pure canola oil $(10,40,70,100,130$, and $160 \mu \mathrm{g} / \mathrm{ml})$ were used to draw a standard curve. The well-established method of Mohammadkhani and Heidari [45] was adopted to estimate the soluble sugars in $H$. annuus and $G$. max leaves. Fresh leaves $(0.5 \mathrm{~g})$ were grounded in the presence of liquid nitrogen and with the help of mortar and pestle. The resultant homogenate was mixed with distilled water $(5 \mathrm{~mL})$ and the mixture was centrifuged at 4,000 $\mathrm{g}$ for $5 \mathrm{~min}$. Supernatent $(0.1 \mathrm{~mL})$ was collected in fresh tube and added $1 \mathrm{~mL}$ of $80 \%$ phenol. The mixture was allowed to stand for 10 minutes at room temperature. After incubation, $5 \mathrm{~mL}$ of concentrated $\mathrm{H}_{2} \mathrm{SO}_{4}$ was added to the mixture and was then incubated at room temperature for an hour. The absorbance was finally observed at $485 \mathrm{~nm}$. Different concentrations of glucose (Sigma Aldrich; 20, 40, 60, 80, and $100 \mu \mathrm{g} / \mathrm{ml}$ ) were taken to plot a standard curve. 


\section{Statistical Analysis}

The data were analyzed by the analysis of variance (ANOVA). The significantly different means were separated by DMRT (Duncan Multiple Range Test) at $\mathrm{p}<0.05$, via SPSS-20 (SPSS Inch., Chicago, IL, USA). Moreover, the significant means were denoted by different letters as a superscript.

\section{Results and Discussion}

\section{Isolation and Plant Growth Promoting Activity} of Fungal Endophytes

Nine isolates of fungal endophytes were isolated from $S$. asper. The potency of the isolated endophytes was tested on $O$. sativa plantlets (results not shown). The endophyte SonchL-27-treated $O$. sativa seedlings have more chlorophyll content (3.5\%), shoot length $(9 \%)$, root length $(15 \%)$, fresh shoot mass $(9.7 \%)$, fresh root mass (74.7\%) and, dry shoot (38\%) and root (26.5\%) mass as compared to the Czapek treated control seedlings (Table 1). SonchL-27 observed to be the best growth promoting endophyte isolated from $S$. asper. The SonchL-27 was, therefore, selected for further experiments and identification.

\section{Molecular Identification of Fungal Isolate SonchL-27}

The nucleotide sequence of the Internal Transcribed Spacer (ITS region) of SonchL-27 isolate was equated with allied strains through the BLAST search program. The $18 \mathrm{~S}$ rDNA sequence revealed maximum resemblance $(100 \%)$ with Stemphylium solani. The phylogenetic tree was prepared from 12 taxa (1 cloned and 11 reference) via $\mathrm{NJ}$ (Neighbor Joining) technique using MEGA-7.0 software (Fig. 1). Results of sequence homology and phylogenetic examination proposed that SonchL-27 as $S$. solani.

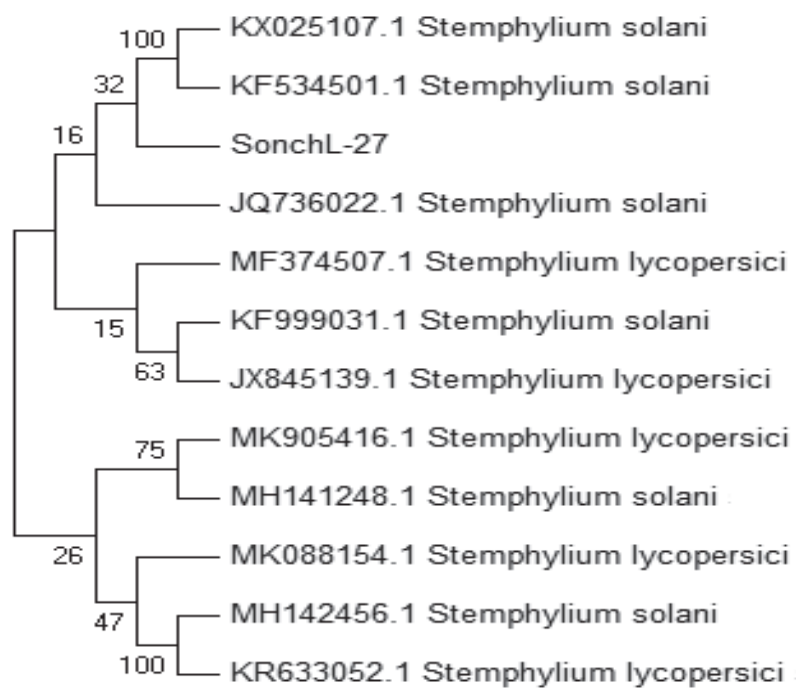

Fig. 1. Molecular identification of isolate SonchL-27 using neighbor joining $(\mathrm{NJ})$ method.

Growth Features of H. annuus and G. max Co-Cultured with $S$. solani

All growth traits (such as chlorophylls, root and shoot lengths, fresh and dry masses of shoot-root) of 14 days old $S$. solani-associated plants grown at normal temperature $\left(25^{\circ} \mathrm{C}\right)$ and thermal stress $\left(40^{\circ} \mathrm{C}\right)$ were measured and compared with control plants. A noteworthy rise was noted in all growth-parameters in G. max and $H$. annuus plantlets allied with $S$. solani as compared to control plantlets. Endophyte-associated $G$. max has enhanced chlorophyll (4.5\%), root length (13\%), shoot length $(25 \%)$, fresh root $(22 \%)$ and shoot weights $(27 \%)$, and dry root $(40 \%)$ and shoot $(28 \%)$ weights, when imperiled to high temperature trauma as related to non-aligned plantlets (Table 2). A likewise improvement was also seen in the chlorophyll contents $(3 \%)$, shoot (7\%) and root lengths (43\%), fresh shoot (34\%) and

Table 1. Result of SonchL-27 filtrate on the development of $O$. sativa plantlets.

\begin{tabular}{|c|c|c|c|}
\hline Development attributes & DW Control & Czk Control & $14.5 \pm .3^{\mathrm{ab}}$ \\
\hline SL $(\mathrm{cm})$ & $12.4 \pm .21^{\mathrm{a}}$ & $13.3 \pm .22^{\mathrm{ab}}$ & $7.5 \pm .13^{\mathrm{b}}$ \\
\hline RL $(\mathrm{cm})$ & $6.2 \pm .18^{\mathrm{a}}$ & $6.5 \pm .28^{\mathrm{ab}}$ & $0.045 \pm .03^{\mathrm{b}}$ \\
\hline FMS (g) & $0.035 \pm .02^{\mathrm{a}}$ & $0.041 \pm .02^{\mathrm{b}}$ & $0.173 \pm .03^{\mathrm{b}}$ \\
\hline FMR (g) & $0.093 \pm .05^{\mathrm{a}}$ & $0.099 \pm .04^{\mathrm{a}}$ & $0.008 \pm .04^{\mathrm{b}}$ \\
\hline DMS (g) & $0.0053 \pm .03^{\mathrm{a}}$ & $0.0058 \pm .04^{\mathrm{a}}$ & $0.021 \pm .04^{\mathrm{b}}$ \\
\hline DMR (g) & $0.0158 \pm .03^{\mathrm{a}}$ & $0.0166 \pm .03^{\mathrm{a}}$ & $23.6 \pm 0.03^{\mathrm{c}}$ \\
\hline Chl content (SPAD) & $20.7 \pm 0.03^{\mathrm{a}}$ & $22.8 \pm 0.03^{\mathrm{b}}$ & ${ }^{\mathrm{a}}$ \\
\hline
\end{tabular}

Czk; Czapek media, DW; Distilled-water, SL; shoot length, RL; root length, FMS; fresh mass shoot, FMR; fresh mass root, DMS; dry mass shoot, DWR; dry mass root, Chl; chlorophyll. Data are mean of 3 replicates with standard error. Data that is followed by different letter is significantly different $(\mathrm{p}<0.05)$ as estimated by Duncan's Multiple Range Test (DMRT). 
Table 2. Result of S. solani on the development of G. max.

\begin{tabular}{|c|c|c|c|c|}
\hline \multirow{2}{*}{$\begin{array}{c}\text { Development } \\
\text { parameters }\end{array}$} & \multicolumn{2}{|c|}{$25^{\circ} \mathrm{C}$} & \multicolumn{2}{c|}{$40^{\circ} \mathrm{C}$} \\
\cline { 2 - 5 } & Control & S. solani & Control & $30.3 \pm 1.6^{\mathrm{ab}}$ \\
\hline Chl content (SPAD) & $30.7 \pm 0.3^{\mathrm{ab}}$ & $33.7 \pm 1.5^{\mathrm{b}}$ & $29 \pm 2^{\mathrm{a}}$ & $32.6 \pm 1.3^{\mathrm{b}}$ \\
\hline SL (cm) & $38.7 \pm 1.8^{\mathrm{c}}$ & $40.8 \pm 0.9^{\mathrm{c}}$ & $26 \pm 0.9^{\mathrm{a}}$ & $11.3 \pm 1^{\mathrm{a}}$ \\
\hline RL (cm) & $16.3 \pm 3.2^{\mathrm{ab}}$ & $17.5 \pm 0.06^{\mathrm{ab}}$ & $10 \pm 0.6^{\mathrm{a}}$ & $1.04 \pm 0.2^{\mathrm{ab}}$ \\
\hline FMS (g) & $1.48 \pm 0.06^{\mathrm{ab}}$ & $1.54 \pm 0.13^{\mathrm{b}}$ & $0.82 \pm 0.37^{\mathrm{a}}$ & $0.162 \pm 0.1^{\mathrm{a}}$ \\
\hline FMR (g) & $0.191 \pm 0.07^{\mathrm{a}}$ & $0.234 \pm 0.02^{\mathrm{a}}$ & $0.133 \pm 0.02^{\mathrm{a}}$ & $0.101 \pm 0.6^{\mathrm{ab}}$ \\
\hline DMS (g) & $0.135 \pm 0.01^{\mathrm{b}}$ & $0.166 \pm 0.01^{\mathrm{c}}$ & $0.079 \pm 0.03^{\mathrm{a}}$ & $0.014 \pm 0.1^{\mathrm{b}}$ \\
\hline DMR (g) & $0.075 \pm 0.002^{\mathrm{c}}$ & $0.088 \pm 0.04^{\mathrm{d}}$ & $0.01 \pm 0.01^{\mathrm{a}}$ & \\
\hline
\end{tabular}

Effect of S. solani on G. max seedlings, isolated from S. asper L. SL; shoot length, RL; root length, FMS; fresh mass shoot, FMR; fresh mass root, DMS; dry mass shoot, DWR; dry mass root, Chl; chlorophyll. Data are mean of 3 replicates with standard error. Data that is followed by different letter is significantly different $(\mathrm{p}<0.05)$ as estimated by Duncan's Multiple Range Test (DMRT).

root weights $(36 \%)$, dry shoot $7.5 \%$ ) and root weights $(25 \%)$ of $S$. solani-associated H. annuus exposed to high temperature stress as compared to the nonassociated seedlings (Table 3). In a similar experiment a high rate of photosynthesis was noted in Capsicum annuum colonized by an endophytic fungi Penicillium resedanum [46] under drought stress. Increase in the frequency of photosynthetic products is linked with increase in the concentrations of chlorophyll. Moreover, endophytes-colonized plants have grater leaf-area as related to non-colonized seedlings [47]. Chlorophyll molecules and thylakoid membrane proteins are damaged by various abiotic stresses causing decline in the rate of photosynthesis, while endophytes are known to restore photosynthetic rate by discouraging the consequences of abiotic pressures [6].

\section{Arbitration of Physiological Features}

In both crops G. max and H. annuus, a higher content of flavonoids and phenolics were detected when grown with $S$. solani as equated to control seedlings, while, reduction was recorded in the concentration of proline contents, at high temperature stress (Fig. 2). An increases in flavonoids and phenolics contents were recorded in $H$. annuus, however, the fungal isolate was lesser effective in G. max in relations to rise in phenolics concentrations as equated to fungal-free seedlings (Fig. 2a-d). In contrast proline contents were reduced in G. max as compared to H. annuus (Fig. 2e-f). Various abiotic and biotic stresses cause accumulation of phenolic compounds in plant species as a defence mechanism [8]. Accumulation of more phenolics in $G$. $\max$ and $H$. annuus plants aligned with $S$. solani at high temperature stress helps in decreasing the consequences of abiotic pressures via hindering the action of ROS [8]. Our findings confirm the results of Abd-Hallah, et al. [48], who reported that plants inoculated with symbiotic partners can accumulate more phenolics under abiotic stresses than non-inoculated ones. Proline, a wellknown organic osmolyte, accumulated during various environmental constrains in plants. Proline has positive

Table 3. Result of S. solani on the development of H. annuus.

\begin{tabular}{|c|c|c|c|c|}
\hline \multirow{2}{*}{$\begin{array}{c}\text { Development } \\
\text { parameters }\end{array}$} & \multicolumn{2}{|c|}{$25^{\circ} \mathrm{C}$} & \multicolumn{2}{c|}{$40^{\circ} \mathrm{C}$} \\
\cline { 2 - 5 } & Control & S. solani & Control & S. solani \\
\hline Chl content (SPAD) & $40 \pm 4.7^{\mathrm{a}}$ & $43.7 \pm 1.6^{\mathrm{a}}$ & $38.4 \pm 1.9^{\mathrm{a}}$ & $39.6 \pm 1.2^{\mathrm{a}}$ \\
\hline SL (cm) & $24.5 \pm 2.1^{\mathrm{a}}$ & $25.4 \pm 1.3^{\mathrm{a}}$ & $20.5 \pm 0.4^{\mathrm{a}}$ & $22 \pm 0.5^{\mathrm{a}}$ \\
\hline RL (cm) & $8.3 \pm 1.2^{\mathrm{ab}}$ & $9.4 \pm 0.5^{\mathrm{b}}$ & $3.5 \pm 0.3^{\mathrm{a}}$ & $5 \pm 0.3^{\mathrm{b}}$ \\
\hline FMS (g) & $1.22 \pm 0.09^{\mathrm{b}}$ & $1.27 \pm 0.12^{\mathrm{b}}$ & $0.781 \pm 0.11^{\mathrm{a}}$ & $1.05 \pm 0.02^{\mathrm{a}}$ \\
\hline FMR (g) & $0.141 \pm 0.02^{\mathrm{ab}}$ & $0.178 \pm 0.04^{\mathrm{b}}$ & $0.075 \pm 0.07^{\mathrm{a}}$ & $0.102 \pm 0.02^{\mathrm{ab}}$ \\
\hline DMS (g) & $0.087 \pm 0.08^{\mathrm{b}}$ & $0.089 \pm 0.07^{\mathrm{b}}$ & $0.04 \pm 0.06^{\mathrm{a}}$ & $0.043 \pm 0.03^{\mathrm{a}}$ \\
\hline DMR (g) & $0.024 \pm 0.01^{\mathrm{b}}$ & $0.029 \pm 0.04^{\mathrm{c}}$ & $0.012 \pm 0.03^{\mathrm{a}}$ & $0.015 \pm 0.02^{\mathrm{a}}$ \\
\hline
\end{tabular}

Effect of S. solani on H. annuus seedlings, isolated from S. asper L. SL; shoot length, RL; root length, FMS; fresh mass shoot, FMR; fresh mass root, DMS; dry mass shoot, DWR; dry mass root, Chl; chlorophyll. Data are mean of 3 replicates with standard error. Data that is followed by different letter is significantly different $(\mathrm{p}<0.05)$ as estimated by Duncan's Multiple Range Test (DMRT). 

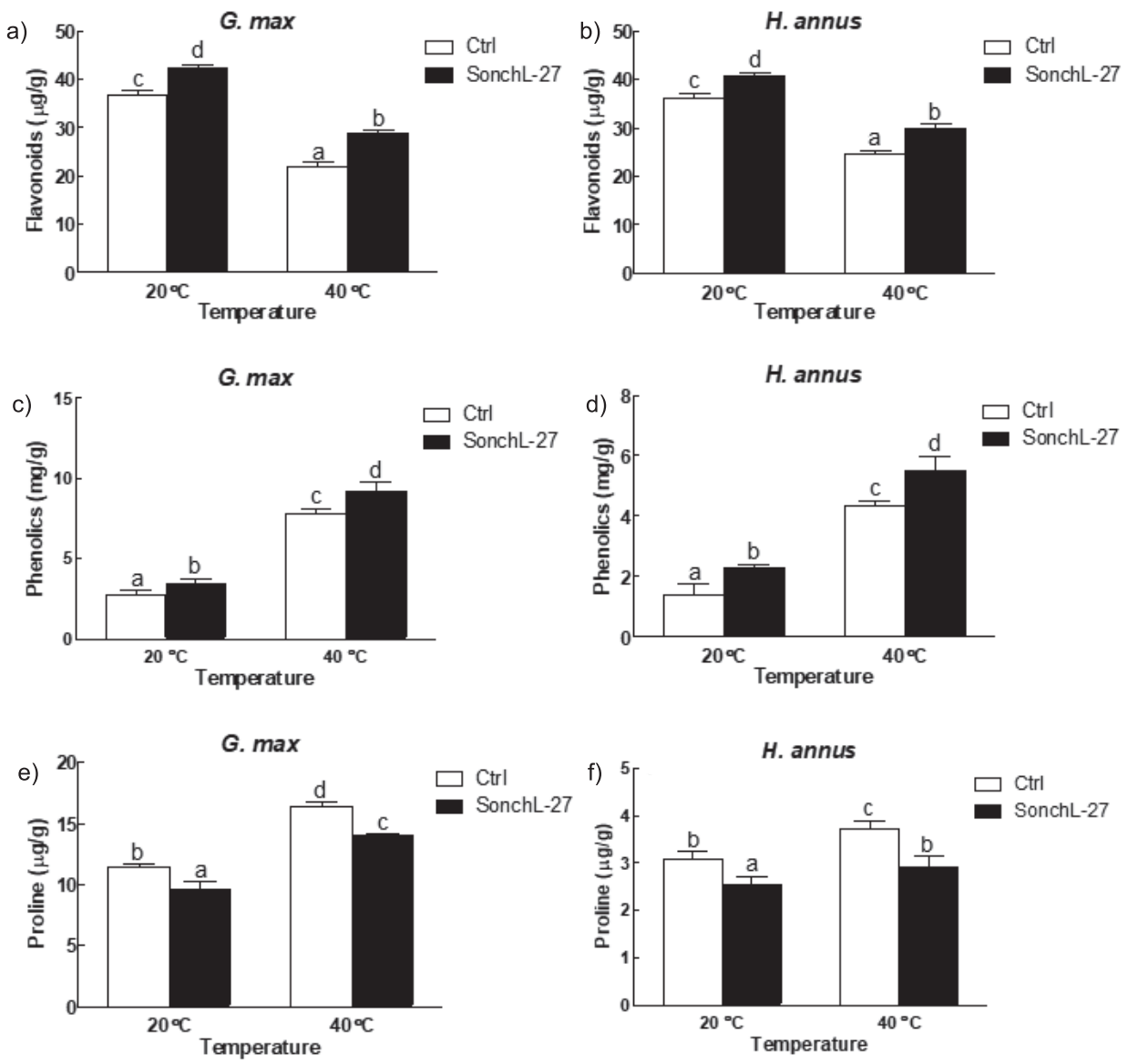

Fig. 2. a) Flavonoids, b) phenolics and b) proline contents of G. max and H. annuus inoculated with and without S. solani (SonchL-27). Data are mean of 3 replicates with standard error. Bars that are represented with different letters are significantly different $(p<0.05)$ as estimated by Duncan's Multiple Range Test (DMRT).

effects on membrane integrity, cellular enzymes, osmotic modification, scavenging of free radicals and buffering of cellular redox potential in plants under abiotic stresses [49].

Endophyte-inoculated $G$. max and $H$. annuus has lower contents of ABA as equated to non-aligned crops at ordinary temperature $\left(25^{\circ} \mathrm{C}\right)$ and heat stress $\left(40^{\circ} \mathrm{C}\right)$. At $25^{\circ} \mathrm{C}, G$. $\max$ associated with $S$. Solani has shown a $19 \%$ reduction in $\mathrm{ABA}$ concentration, while at $40^{\circ} \mathrm{C}$, a $22 \%$ fall was recorded. Likewise, in $H$. annuus a $10 \%$ decrease in ABA contents was recorded at $25^{\circ} \mathrm{C}$, while $15 \%$ was noted at $40^{\circ} \mathrm{C}$, when inoculated with $S$. solani as compared to the non-associated seedlings grown at ordinary temperature and thermal stress (Fig. 3a-b). Abscisic acid, commonly known as stress hormone, which accrues in all plants subjected to abiotic pressures, including heat stress. ABA catabolism can be strongly inhibited by heat stress in plants through down regulation of the genes accountable for ABA degradation [50]. In current work, a high concentration of ABA was noticed in $S$. solani-free soybean and sunflower plants as related to inoculated ones under high temperature stress. This elevation of ABA hormone in endophyte-free seedlings of sunflower and soybean might be due to up-regulation of ABA synthesis genes or a decrease in ABA catabolism. Our findings for lower amount of ABA in endophyte assisted $G$. $\max$ and $H$. annuus also confirms the findings of Hamayun, et al. [15]. Reduction in the concentrations of ABA in endophyte-inoculated plants may be due to the participation of gibberellins (GAs), as foliar application of GAs enhanced stress tolerance in G. max escorted by reduced amounts of ABA. In an earlier study on an endophytic fungus Aspergillus flavus, similar results were recorded by Ismail, et al. [7] for G. max and H. annuus under thermal stress. In current research, we also observed a positive change in the amount of primary metabolites (sugars, proteins and lipids) in endophyte inoculated G. max and H. annuus. The results indicated the possible use of $S$. solani as an alternate to chemical fertilizer and to achieve sustanablity through natural resources.

We also found an enhanced level of $\mathrm{H}_{2} \mathrm{O}_{2}$ and lipids peroxidation in control plants of $G$. $\max$ and $H$. annuus at high temperature stress. It is known that elevated level of $\mathrm{H}_{2} \mathrm{O}_{2}$ has negative impact on membranes activity. Amount of lipids per-oxidation is linked to the MDA synthesis. A substantial reduction 

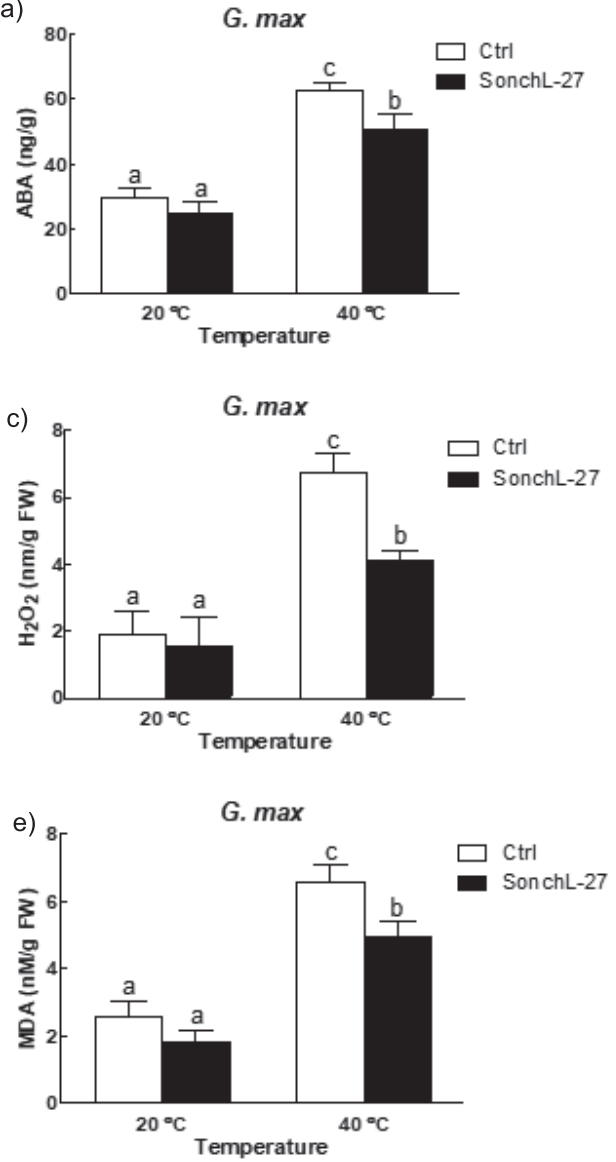
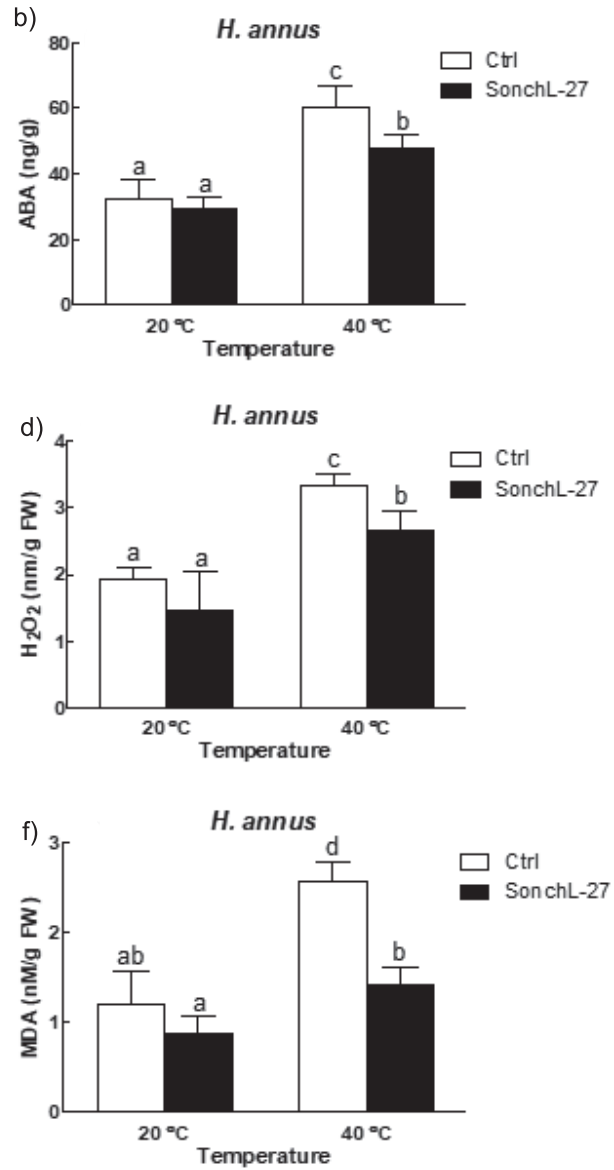

Fig. 3. a) ABA b) Hydrogen peroxide $\left(\mathrm{H}_{2} \mathrm{O}_{2}\right)$ and Lipid peroxidation (MDA) in G. max and H. annuus inoculated with and without $S$. solani (SonchL-27). Data are mean of 3 replicates with standard error. Bars that are represented with different letters are significantly different $(\mathrm{p}<0.05)$ as estimated by Duncan's Multiple Range Test (DMRT).

in MDA concentrations was recorded in $S$. solanialigned G. max and H. annuus. At normal temperature, a $42.5 \%$ drop in the contents of MDA was noted in $G$. $\max$, while $40 \%$ drop was noted in $H$. annuus when co-cultured with $S$. solani (Fig. 3c-d). S. solaniassociated $G$. max and $H$. annuus also showed reduction in the levels of $\mathrm{H}_{2} \mathrm{O}_{2}$ by $23.7 \%$ and $33 \%$, respectively at $25^{\circ} \mathrm{C}$, whereas, at heat stress $65 \%$ reduction was noted in G. $\max$ and $26 \%$ decrease was recorded in $H$. annuus (Fig. 3e-f). Thermal stress initiates complicated biochemical responses in higher plants. These biochemical responses constitutes modifications in osmotic potential, formation of heat shock proteins (HSPs), membrane lipids and antioxidant systems [48]. In current study, we determined the potential strength of an endophytic fungus $S$. solani at heat stress while inoculated to $G$. $\max$ and $H$. annuus. It was noted that S. solani-inoculated G. $\max$ and H. annuus were highly resistant to temperature pressure as related to non-inoculated plants. Biochemical, physiological and transcriptional machineries are highly affected by heat stress. Oxidative stress caused by high temperature results in elevated contents of MDA that in turn indicates lipids peroxidation. In current work, it is noted that G. max and H. annuus both have lesser amount of MDA when innoculated with $S$. solani as related to endophyte-free plants under thermal stress. Increase in MDA concentrations has negative effect on cellular membranes. However, endophytes (bacteria and fungi) are known to have positive role in host plants resistance that leads to a reduction in total MDA concentration under abiotic stresses. Our findings are in agreement with Abd-Hallah, et al. [48], who reported that endophytes can ameliorate abiotic traumas in chickpea by falling MDA and $\mathrm{H}_{2} \mathrm{O}_{2}$ concentrations. Moreover, high temperature stress, enhances $\mathrm{H}_{2} \mathrm{O}_{2}$ synthesis in plants that can disturb membrane structural integrity as well as leads to lipids peroxidation $[6,51]$.

Soluble sugars, lipids and proteins of $G$. $\max$ and $H$. annuus were quantified through spectrophotometer. A $16 \%$ and $30 \%$ increase in the amount of lipids was recorded at $25^{\circ} \mathrm{C}$ in endophyte associated $G$. $\max$ and $H$. annuus plants. Endophyte-inoculated G. $\max$ has $22 \%$ and $H$. annuus has $27 \%$ extra protein at high temperature, while at normal temperature both $G$. $\max$ and $H$. annuus have $5 \%$ higher protein contents as compared to non-inoculated seedlings (Fig. 4a-b). Whereas, at $40^{\circ} \mathrm{C}, S$. solani-aligned G. $\max$ has $11.5 \%$ and $H$. annuus has $17 \%$ higher level of sugars, whereas at $25^{\circ} \mathrm{C}, G$. max has same while, $H$. annuus has $12 \%$ 

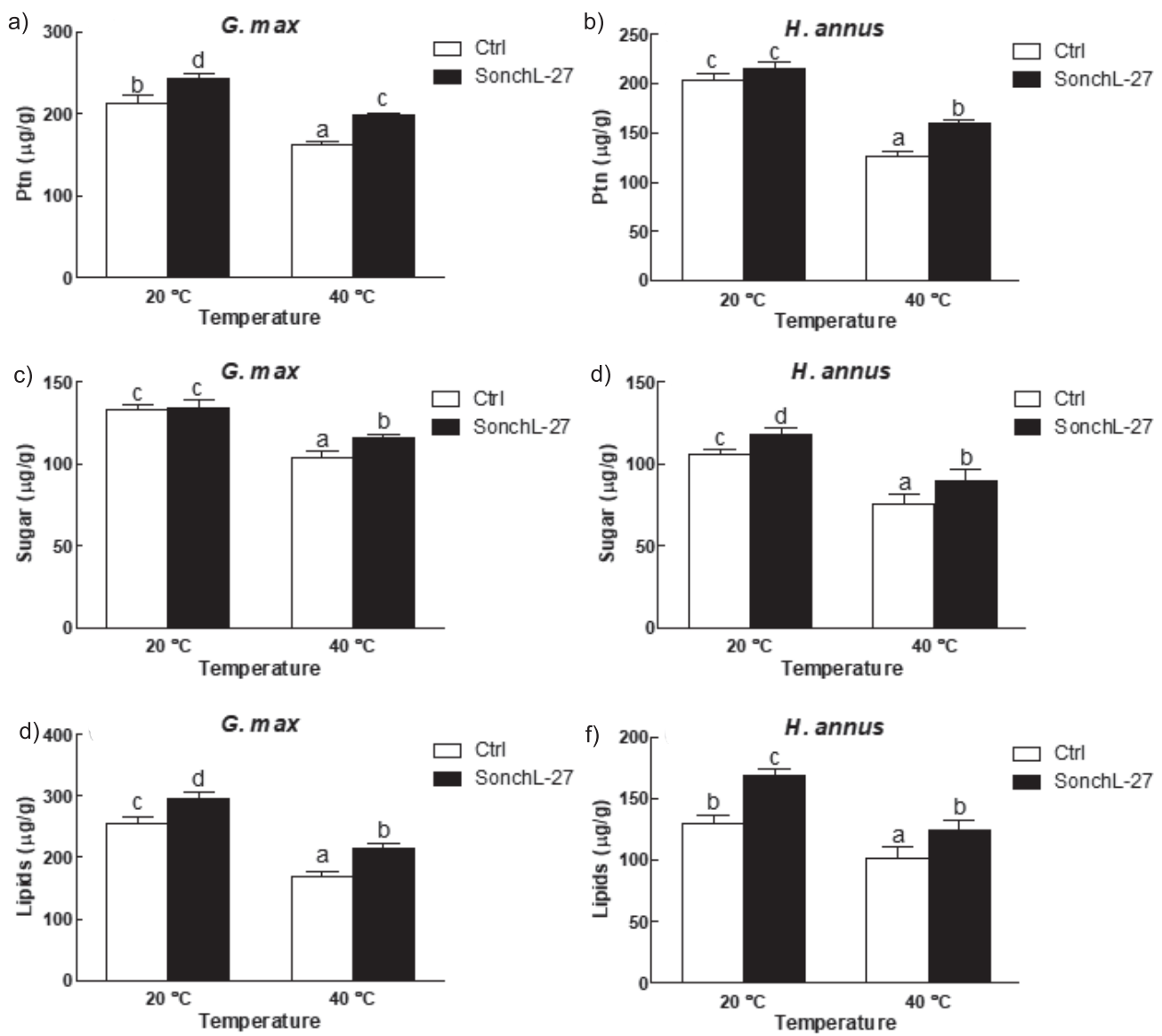

Fig. 4. Analysis of total proteins a), soluble sugars b) and lipids c) of G. max and H. annuus inoculated with and without $S$. solani (SonchL-27). Data are mean of 3 replicates with standard error. Bars that are represented with different letters are significantly different $(\mathrm{p}<0.05)$ as estimated by Duncan's Multiple Range Test (DMRT).

higher level of sugars as compared to the S. solanifree seedlings (Fig. $4 \mathrm{c}-\mathrm{d}$ ). At $40^{\circ} \mathrm{C}, \mathrm{S}$. solani-associated G. $\max (26 \%)$ and H. annuus $(22 \%)$ has higher level of lipids than non-associated plantlets (Fig. 4e-f).

A substantial increase was noticed in antioxidants activities, including AAO, POD, CAT, GR and SOD in endophyte-aligned $G$. max and $H$. annuus seedlings at $40^{\circ} \mathrm{C}$ as equated to non-aligned $S$. solani seedlings. S. solani-aligned G. max plants have boosted levels of
AAO (37\%), POD (45\%), CAT (56\%), GR (15\%), and SOD (27\%). Similar observations were recorded in S. solani-aligned $H$. annuus in terms of AAO $(21 \%)$, POD (25\%), CAT (71\%), GR (36\%) and SOD (22\%) as equated to endophyte-free plantlets (Table 4 and 5). This ameliorative role of fungal endophytes might be due to ROS deterioration by strengthening antioxidant systems and an enhancement in nutrients uptake [52]. Superoxide radicals and $\mathrm{H}_{2} \mathrm{O}_{2}$ can be normalized

Table 4. Result of $S$. solani on the activity of antioxidant enzymes in G. $\max$.

\begin{tabular}{|c|c|c|c|c|}
\hline \multirow{2}{*}{ Enzyme } & \multicolumn{2}{|c|}{$25^{\circ} \mathrm{C}$} & \multicolumn{2}{c|}{$40^{\circ} \mathrm{C}$} \\
\cline { 2 - 5 } & Control & S. solani & Control & $2.53 \pm 0.23^{\mathrm{c}}$ \\
\hline AAO (Unit/g/30 sec.) & $1.57 \pm 0.09^{\mathrm{a}}$ & $1.67 \pm 0.05^{\mathrm{a}}$ & $1.82 \pm 0.14^{\mathrm{b}}$ & $1.48 \pm 0.07^{\mathrm{d}}$ \\
\hline CAT (Unit/g/30 sec.) & $0.40 \pm 0.05^{\mathrm{a}}$ & $0.77 \pm 0.05^{\mathrm{b}}$ & $0.89 \pm 0.05^{\mathrm{c}}$ & $6.60 \pm 0.33^{\mathrm{d}}$ \\
\hline POD (U/mg protein) & $1.09 \pm 0.07^{\mathrm{a}}$ & $1.29 \pm 0.14^{\mathrm{b}}$ & $4.55 \pm 0.51^{\mathrm{c}}$ & $52 \pm 2.01^{\mathrm{c}}$ \\
\hline SOD (U/mg protein) & $20 \pm 1.37^{\mathrm{a}}$ & $21 \pm 0.75^{\mathrm{a}}$ & $42 \pm 1.92^{\mathrm{b}}$ & $1.90 \pm 0.18^{\mathrm{c}}$ \\
\hline GR (U/mg protein) & $1.35 \pm 0.19^{\mathrm{a}}$ & $1.43 \pm 0.17^{\mathrm{a}}$ & $1.58 \pm 0.05^{\mathrm{b}}$ & \\
\hline
\end{tabular}

Effect of S. solani on G. max seedlings, isolated from S. asper L. AAO; ascorbic acid oxidase; CAT; catalase; POD; peroxidase, SOD; superoxide dismutase; GR; glutathione reductase. Data are mean of 3 replicates with standard error. Data that is followed by different letter is significantly different $(\mathrm{p}<0.05)$ as estimated by Duncan's Multiple Range Test (DMRT). 
Table 5. Result of S. solani on antioxidant enzymes activity in H. annuus.

\begin{tabular}{|c|c|c|c|c|}
\hline \multirow{2}{*}{ Enzyme } & \multicolumn{2}{|c|}{$25^{\circ} \mathrm{C}$} & \multicolumn{2}{c|}{$40^{\circ} \mathrm{C}$} \\
\cline { 2 - 5 } & Control & S. solani & Control & $2.75 \pm 0.23^{\mathrm{c}}$ \\
\hline AAO (Unit/g/30 sec.) & $0.61 \pm 0.09^{\mathrm{a}}$ & $0.86 \pm 0.04^{\mathrm{b}}$ & $2.27 \pm 0.29^{\mathrm{c}}$ & $1.03 \pm 0.15^{\mathrm{d}}$ \\
\hline CAT (Unit/g/30 sec.) & $0.21 \pm 0.05^{\mathrm{a}}$ & $0.49 \pm 0.08^{\mathrm{b}}$ & $0.49 \pm 0.08^{\mathrm{c}}$ & $4.40 \pm 0.21^{\mathrm{d}}$ \\
\hline POD (U/mg protein) & $0.92 \pm 0.11^{\mathrm{a}}$ & $1.11 \pm 0.07^{\mathrm{b}}$ & $3.51 \pm 0.47^{\mathrm{c}}$ & $33 \pm 1.65^{\mathrm{d}}$ \\
\hline SOD (U/mg protein) & $13 \pm 1.41^{\mathrm{a}}$ & $17 \pm 0.78^{\mathrm{b}}$ & $27 \pm 1.06^{\mathrm{c}}$ & $2.63 \pm 0.06^{\mathrm{c}}$ \\
\hline GR (U/mg protein) & $0.59 \pm 0.09^{\mathrm{a}}$ & $0.74 \pm 0.10^{\mathrm{a}}$ & $1.98 \pm 0.17^{\mathrm{b}}$ & \\
\hline
\end{tabular}

Effect of S. solani on H. annuus seedlings, isolated from S. asper L. AAO; ascorbic acid oxidase; CAT; catalase; POD; peroxidase, SOD; superoxide dismutase; GR; glutathione reductase. Data are mean of 3 replicates with standard error. Data that is followed by different letter is significantly different $(\mathrm{p}<0.05)$ as estimated by Duncan's Multiple Range Test (DMRT).

by one of the vital antioxidant enzymes system, i.e SOD. Besides, tress toxicity is ameliorated by higher concentrations of POD that have role in the generation of protective compounds, synthesis and strengthening of the lignins [53] $\mathrm{H}_{2} \mathrm{O}_{2}$ functions as signaling molecule that diffuse quickly via membranes and organelles causing injury, CAT can scavenge the $\mathrm{H}_{2} \mathrm{O}_{2}$ and hence protect the plant form damages [54]. AAO and GR are important compounds of ROS degrading pathway that comprises the ascorbate-glutathione cycle [55]. A sequence of oxidation-reduction reactions arises in the ascorbate glutathione cycle, resulting in the exclusion of $\mathrm{H}_{2} \mathrm{O}_{2}$ in chloroplast and cytoplasm to diminish the toxicity of oxidative-stress.

\section{Conclusions}

$S$. solani has improved the overall growth features in $G$. max and H. annuus. Besides, the potent endophyte has facilitated the host crops to resist thermal stress by improving antioxidant system. Certainly, higher production of AAO, POD, CAT, GR, SOD, phenolics and flavonoids in $S$. solani associated $G$. $\max$ and $H$. annuus under thermal stress tackled the ROS efficiently. Therefore, we concluded that the use of $S$. solani as biostimulant in crops exposed to higher temperature will lead to sustainable agriculture.

\section{Acknowledgments}

This research was supported by the Basic Science Research Program through the National Research Foundation of Korea (NRF) funded by the Ministry of Education (2017R1D1A1B04035601).

\section{Conflict of Interest}

The authors declare no conflict of interest.

\section{References}

1. FAHAD S., BAJWA A. A., NAZIR U., ANJUM S. A., FAROOQ A., ZOHAIB A., SADIA S., NASIM W., ADKINS S., SAUD S. Crop production under drought and heat stress: plant responses and management options. Front. Plant Sci. 8, 1147, 2017.

2. FAHAD S., HUSSAIN S., SAUD S., KHAN F., HASSAN S., NASIM W., ARIF M., WANG F., HUANG J. Exogenously applied plant growth regulators affect heat-stressed rice pollens. Journal of agronomy and crop science. 202 (2), 139, 2016.

3. FAHAD S., HUSSAIN S., SAUD S., TANVEER M., BAJWA A.A., HASSAN S., SHAH A.N., ULLAH A., WU C., KHAN F. A. A biochar application protects rice pollen from high-temperature stress. Plant Physiol. Biochem. 96, 281, 2015.

4. FAHAD S., IHSAN M. Z., KHALIQ A., DAUR I., SAUD S., ALZAMANAN S., NASIM W., ABDULLAH M., KHAN I.A., WU C. Consequences of high temperature under changing climate optima for rice pollen characteristics-concepts and perspectives. Archives of Agronomy and Soil Science. 64 (11), 1473, 2018.

5. HATFIELD J.L., PRUEGER J.H. Temperature extremes: Effect on plant growth and development. Weather and climate extremes. 10, 4, 2015.

6. ISMAIL, MUHAMMAD H., HUSSAIN A., IQBAL A., KHAN S.A., KHAN M.A., LEE I.-J. An Endophytic Fungus Gliocladium cibotii Regulates Metabolic and Antioxidant System of Glycine max and Helianthus annuus under Heat Stress. Polish Journal of Environmental Studies. 30, 1, 2021.

7. ISMAIL, HAMAYUN M., HUSSAIN A., AFZAL KHAN S., IQBAL A., LEE I.-J. Aspergillus flavus promoted the growth of soybean and sunflower seedlings at elevated temperature. Biomed Res. Int. 2019, 1, 2019.

8. ISMAIL, HAMAYUN M., HUSSAIN A., IQBAL A., KHAN S. A., LEE I.-J. Endophytic fungus Aspergillus japonicus mediates host plant growth under normal and heat stress conditions. Biomed Res. Int. 2018, 2018.

9. ISMAIL, ANWAR H., MEHMOOD A., QADIR M., HUSNA, IQBAL A., HAMAYUN M., KHAN N. Thermal stress alleviating potential of endophytic fungus Rhizopus oryzae inoculated to sunflower (Helianthus annuus L.) And soybean (Glycine max L.). Pakistan Journal of Botany. 52, 5, 2020 . 
10. ISMAIL, MUHAMMAD H., ANWAR H., AMJAD I., SUMERA A. K., IN-JUNG L. Aspergillus niger boosted heat stress tolerance in sunflower and soybean via regulating their metabolic and antioxidant system. Journal of Plant Interactions. 15, 223, 2020.

11. ALQARAWI A. A., ABD ALLAH E., HASHEM A. Alleviation of salt-induced adverse impact via mycorrhizal fungi in Ephedra aphylla Forssk. J. Plant Interact. 9 (1), 802, 2014

12. ASSAHA D.V., UEDA A., SANEOKA H., AL-YAHYAI R., YAISH M.W. The role of $\mathrm{Na}+$ and $\mathrm{K}+$ transporters in salt stress adaptation in glycophytes. Front. Physiol. 8, 509, 2017.

13. ABD-HALLAH E.F., HASHEM A., ALQARAWI A.A., BAHKALI A.H., ALWHIBI M.S. Enhancing growth performance and systemic acquired resistance of medicinal plant Sesbania sesban (L.) Merr using arbuscular mycorrhizal fungi under salt stress. Saudi J. Biol. Sci. 22 (3), 274, 2015.

14. HAMAYUN M., HUSSAIN A., KHAN S.A., IRSHAD M., KHAN A.L., WAQAS M., SHAHZAD R., IQBAL A., ULLAH N., REHMAN G. Kinetin modulates physiohormonal attributes and isoflavone contents of Soybean grown under salinity stress. Front. Plant Sci. 6, 377, 2015.

15. HAMAYUN M., HUSSAIN A., KHAN S.A., KIM H.-Y., KHAN A.L., WAQAS M., IRSHAD M., IQBAL A., REHMAN G., JAN S. Gibberellins producing endophytic fungus Porostereum spadiceum AGH786 rescues growth of salt affected soybean. Front Microbiol. 8, 1, 2017.

16. KHAN M.A., HAMAYUN M., IQBAL A., KHAN S.A., HUSSAIN A., ASAF S., KHAN A.L., YUN B.-W., LEE I.-J. Gibberellin application ameliorates the adverse impact of short-term flooding on Glycine max L. Biochem. J. 475 (18), 2893, 2018.

17. BILAL L., ASAF S., HAMAYUN M., GUL H., IQBAL A., ULLAH I., LEE I.-J., HUSSAIN A. Plant growth promoting endophytic fungi Asprgillus fumigatus TS1 and Fusarium proliferatum BRL1 produce gibberellins and regulates plant endogenous hormones. Symbiosis. 76 (2), 117, 2018.

18. NUSRAT B., GUL J., FARZANA G.J., MUHAMMAD H., AMJAD I., ANWAR H., HAZIR R., ABDUL T., FAIZA K. Cochliobolus sp. acts as a biochemical modulator to alleviate salinity stress in okra plants. Plant Physiol. Biochem. 139, 459, 2019.

19. GUL JAN F., HAMAYUN M., HUSSAIN A., IQBAL A., JAN G., KHAN S. A., KHAN H., LEE I.-J. A promising growth promoting Meyerozyma caribbica from Solanum xanthocarpum alleviated stress in maize plants. Biosci. Rep. 39, 1, 2019.

20. SAH S. K., REDDY K. R., LI J. Abscisic acid and abiotic stress tolerance in crop plants. Front. Plant Sci. 7, 571, 2016.

21. MIERZIAK J., KOSTYN K., KULMA A. Flavonoids as important molecules of plant interactions with the environment. Molecules. 19 (10), 16240, 2014.

22. MUHAMMAD I., NIAZ A., GUL J., AMJAD I., MUHAMMAD H., FARZANA G. J., ANWAR H., INJUNG L. Trichoderma reesei improved the nutrition status of wheat crop under salt stress. J. Plant Interact. 14, 590, 2019.

23. KHUSHDIL F., JAN F.G., JAN G., HAMAYUN M., IQBAL A., HUSSAIN A., BIBI N. Salt stress alleviation in Pennisetum glaucum through secondary metabolites modulation by Aspergillus terreus. Plant Physiol. Biochem. 144, 127, 2019.
24. QADIR M., HUSSAIN A., HAMAYUN M., SHAH M., IQBAL A., MURAD W. Phytohormones producing rhizobacterium alleviates chromium toxicity in Helianthus annuus L. by reducing chromate uptake and strengthening antioxidant system. Chemosphere. 127386, 2020.

25. RAID A., HUMAIRA G., MUHAMMAD H., MAMOONA R., AMJAD I., MOHIB S., ANWAR H., HAMIDA B., IN-JUNG L. Aspergillus awamori ameliorates the physicochemical characteristics and mineral profile of mung bean under salt stress. Chemical and Biological Technologies in Agricutlure. 8, 1, 2021.

26. MEHMOOD A., HUSSAIN A., IRSHAD M., HAMAYUN M., IQBAL A., KHAN N. In vitro production of IAA by endophytic fungus Aspergillus awamori and its growth promoting activities in Zea mays. Symbiosis. 77, 225, 2019.

27. MEHMOOD A., HUSSAIN A., IRSHAD M., HAMAYUN M., IQBAL A., RAHMAN H., TAWAB A., AHMAD A., AYAZ S. Cinnamic acid as an inhibitor of growth, flavonoids exudation and endophytic fungus colonization in maize root. Plant Physiol. Biochem. 135, 61, 2019.

28. KANG S.-M., HAMAYUN M., KHAN M. A., IQBAL A., LEE I.-J. Bacillus subtilis JW1 enhances plant growth and nutrient uptake of Chinese cabbage through gibberellins secretion. J. Appl. Bot. Food Qual. 92, 172, 2019.

29. BENIZRI E., COURTADE A., PICARD C., GUCKERT A. Role of maize root exudates in the production of auxins by Pseudomonas fluorescens M. 3.1. Soil Biology and Biochemistry. 30 (10-11), 1481, 1998.

30. WARRIER R., PAUL M., VINEETHA M. Estimation of salicylic acid in Eucalyptus leaves using spectrophotometric methods. Genetics and Plant Physiology. 3 (1-2), 90, 2013.

31. KHAN S. A., HAMAYUN M., YOON H., KIM H.Y., SUH S.-J., HWANG S.-K., KIM J.-M., LEE I.-J., CHOO Y.-S., YOON U.-H. Plant growth promotion and Penicillium citrinum. BMC Microbiol. 8 (1), 231, 2008.

32. CHEN W.-P., KUO T.-T. A simple and rapid method for the preparation of gram-negative bacterial genomic DNA. Nucleic Acids Res. 21 (9), 2260, 1993.

33. MISRA N., DWIVEDI U. Genotypic difference in salinity tolerance of green gram cultivars. Plant Sci. 166 (5), 1135, 2004.

34. ISMAIL, HAMAYUN M., HUSSAIN A., AFZAL KHAN S., IQBAL A., LEE I.-J. Aspergillus niger boosted heat stress tolerance in sunflower and soybean via regulating their metabolic and antioxidant system. Journal of Plant Interactions. 15, 223, 2020.

35. LUCK H. Methods in Enzymatic Analysis II (ed.) Bergmeyer. (Publ.), Academic Press, New York: 1974.

36. KAR M., MISHRA D. Catalase, peroxidase, and polyphenoloxidase activities during rice leaf senescence. Plant Physiol. 57 (2), 315, 1976.

37. OBERBACHER M., VINES H. Spectrophotometric assay of ascorbic acid oxidase. Nature. 197 (4873), 1203, 1963.

38. BEYER JR W.F., FRIDOVICH I. Assaying for superoxide dismutase activity: some large consequences of minor changes in conditions. Anal. Biochem. 161 (2), 559, 1987.

39. CARLBERG I., MANNERVIK B. [59] Glutathione reductase, Elsevier: 484, 1985.

40. YOON J. Y., HAMAYUN M., LEE S.-K., LEE I.-J. Methyl jasmonate alleviated salinity stress in soybean. Journal of Crop Science and Biotechnology. 12 (2), 63, 2009.

41. CAI Y., LUO Q., SUN M., CORKE H. Antioxidant activity and phenolic compounds of 112 traditional Chinese medicinal plants associated with anticancer. Life Sci. 74 (17), 2157, 2004. 
42. BATES L.S., WALDREN R.P., TEARE I. Rapid determination of free proline for water-stress studies. Plant and Soil. 39 (1), 205, 1973.

43. LOWRY O.H., ROSEBROUGH N.J., FARR A.L., RANDALL R.J. Protein measurement with the Folin phenol reagent. J. Biol. Chem. 193, 265, 1951.

44. VAN HANDEL E. Rapid determination of total lipids in mosquitoes. J. Am. Mosq. Control Assoc. 1 (3), 302, 1985.

45. MOHAMMADKHANI N., HEIDARI R. Drought-induced accumulation of soluble sugars and proline in two maize varieties. World Appl. Sci. J. 3 (3), 448, 2008.

46. KHAN A. L., WAQAS M., LEE I.-J. Resilience of Penicillium resedanum LK6 and exogenous gibberellin in improving Capsicum annuum growth under abiotic stresses. J Plant Res. 128 (2), 259, 2015.

47. DASTOGEER K.M., WYLIE S.J. Plant-Fungi Association: Role of fungal endophytes in improving plant tolerance to water stress, Springer: Singapore, 143, 2017.

48. ABD-HALLAH E.F., ALQARAWI A.A., HASHEM A., RADHAKRISHNAN R., AL-HUQAIL A.A., AL-OTIBI F.O.N., MALIK J.A., ALHARBI R.I., EGAMBERDIEVA D. Endophytic bacterium Bacillus subtilis (BERA 71) improves salt tolerance in chickpea plants by regulating the plant defense mechanisms. Journal of Pant Interactions. 13 (1), 37, 2018.

49. HOSSAIN M.A., HOQUE M.A., BURRITT D.J., FUJITA M. Proline protects plants against abiotic oxidative stress: biochemical and molecular mechanisms, Elsevier: 477$522,2014$.
50. LONG H., ZHENG Z., ZHANG Y., XING P., WAN X., ZHENG Y., LI L. An abscisic acid (ABA) homeostasis regulated by its production, catabolism and transport in peanut leaves in response to drought stress. PloS one. 14 (6), e0213963, 2019.

51. ISMAIL, MUHAMMAD H., HUSSAIN A., IQBAL A., KHAN S.A., GUL S., KHAN H., REHMAN K.U., BIBI H., LEE I.-J. Penicillium Glabrum acted as a heat stress relieving endophyte in soybean and sunflower. Pol J Environ Stud. 30, 3099, 2021.

52. CHANG J., WANG Y., SHAO L., LABERGE R.-M., DEMARIA M., CAMPISI J., JANAKIRAMAN K., SHARPLESS N.E., DING S., FENG W. Clearance of senescent cells by ABT263 rejuvenates aged hematopoietic stem cells in mice. Nat. Med. 22 (1), 78, 2016.

53. LIU Q., LUO L., ZHENG L. Lignins: biosynthesis and biological functions in plants. International journal of molecular sciences. 19 (2), 335, 2018.

54. BIENERT G.P., CHAUMONT F. Aquaporin-facilitated transmembrane diffusion of hydrogen peroxide. Biochim. Biophys. Acta Biochim Biophys Acta. 1840 (5), 1596, 2014.

55. HASANUZZAMAN M., BHUYAN M., ANEE T.I., PARVIN K., NAHAR K., MAHMUD J.A., FUJITA M. Regulation of ascorbate-glutathione pathway in mitigating oxidative damage in plants under abiotic stress. Antioxidants. 8 (9), 384, 2019. 